\section{Lembaran Sejarah}

\title{
Midwives and Dukun Beranak, the Choices for Handling Child dbirth
}

\author{
NUR JANTI \\ Independent Researcher \\ Email: jantinur.nj@gmail.com
}

\begin{abstract}
Since the colonial era, there have been attempts to provide clinical childbirth services by establishing midwifery schools. Although these schools were closed, reorganized then re-opened several times, in an effort to graduate native midwives in the colony. The majority of the European doctors believed the existence of native midwives could reduce mortality rates for difficult deliveries. The colonial government also tried to replace dukun beranak (local midwives) with graduate midwives, as many doctors considered dukun beranak practices unsafe and unhygienic. Of note, even though midwifery school graduates provided childbirth services, most of the population preferred to use dukun beranak. This situation continued until independence. Dukun beranak remained the preferred provider of assistance among the working and lower class. The continued popularity of the dukun beranak can be seen as a colonial failure to replace them. After the proclamation of Indonesian independence, midwives who supported the Indonesian Republic, still provided childbearing assistance although with limited infrastructure and inadequate personnel during the independence war. Midwives also founded a midwifes association, rebuilt the national midwifery system, and discontinued colonial elements. This transformation can be interpreted as the decolonisation of midwifery. Midwives and dukun beranak were the available options for assisting in the labour of an Indonesian woman. The Indonesian government had a different approach to the colonial government toward society and dukun beranak and built cooperation between midwives and the dukun beranak. The cooperative work among midwives and dukun beranak changed awareness of Indonesian women's reproductive health matters. This article traces efforts to provide safer childbirth services by looking at the problem through the lens of midwives and dukun beranak relations. The evolution of this relationship shows the decolonisation process inside midwifery and childbearing services.
\end{abstract}

\begin{abstract}
Abstrak
Sejak periode kolonial, telah ada beragam usaha untuk menyediakan jasa pelayanan kesehatan ibu dan anak lewat pendirian sekolah kebidanan. Sekolah-sekolah ini sering ditutup, direorganisasi lalu dibuka kembali. Mayoritas dokter Eropa percaya bahwa keberadaan bidan pribumi dapat mengurangi kematian akibat dari proses kelahiran. Pemerintah kolonial berusaha untuk menggantikan dukun beranak dengan bidan resmi lulusan sekolah negara karena kepercayaan banyak dokter
\end{abstract}

\section{Keywords:}

dukun;

Indonesian

independence; midwives

Kata kunci: bidan; dukun; kemerdekaan Indonesia

*) My utmost appreciation to Julia Suryakusuma, who greatly helped to proofread and edit this paper. 
bahwa praktek dukun beranak itu tidak aman dan tidak higienis. Menariknya, walaupun bidan lulusan sekolah resmi menyediakan jasa kelahiran anak, sebagian penduduk lebih memilih menggunakan jasa dukun beranak. Situasi ini berlanjut sampai setelah merdeka. Dukun beranak tetap menjadi jasa kelahiran utama bagi kelas pekerja dan rendah. Terus populernya dukun beranak dapat dilihat sebagai kegagalan kolonialisme. Setelah proklamasi kemerdekaan, bidan yang mendukung republik tetap menyediakan jasa kelahiran walaupun berhadapan dengan prasarana dan personel yang terbatas pada periode perang kemerdekaan. Para bidan juga mendirikan asosiasi perbidanan, mendirikan ulang sistem kebidanan nasional dan menghapus elemen-elemen kolonial. Perubahan ini dapat dilihat sebagai dekolonisasi perbidanan. Bidan dan dukun beranak menjadi penyedia jasa utama dalam membantu kelahiran perempuan Indonesia. Pemerintah Indonesia memilih pendekatan yang berbeda dengan pemerintah kolonial dengan cara membentuk kerjasama yang erat antara bidan dan dukun beranak. Kerjasama antara bidan dan dukun beranak mengubah kesadaran perempuan Indonesia seputaran kesehatan reproduktif. Artikel ini menelusuri usaha-usaha untuk menyediakan jasa kelahiran yang lebih aman dengan melihat permasalahan dari sudut pandang hubungan bidan dengan dukun beranak. Perkembangan hubungan ini menunjukkan proses dekolonisasi dalam jasa perbidanan.

\section{Introduction}

In recent decades, dukun beranak no longer assists in childbearing and their work has become limited to massaging and bathing babies, becoming dukun bayi that is a dukun providing services only for babies. In 2008, the Ministry of Health issued Decree No. 828 stipulating the relationship between dukun and midwives. This decree forbade dukun beranak to assist a woman during labour and only permitted them to handle non-medical, postnatal treatment for the mother and newborn baby.

The term dukun beranak is synonymous with dukun bayi. The former is mostly used in Jakarta, while the Javanese usually use the latter term. The Sundanese in West Java however, use the term Mak Paraji coming from the Sundanese language.

The word dukun does not originate from Malay, Indonesian, or any local languages. According to Jennifer Nourse dukun comes from the Persian word Deh, meaning a village or town, and qhan, meaning leader or prince. When the two words are combined, it becomes dehqhan or dehqn: a person of great wealth or sharpness or quickness of intellect (Nourse, 2013:403).

In the early encounters between Europeans and the dukun, Europeans formed a positive view of the dukun and they judged local herbal knowledge positively. Physicians and botanists in the $17^{\text {th }}$ century, such as Jacobus Bontius and Georgius Everhardus Rumphius who conducted their research in the Indies, were impressed by the indigenous people's knowledge of medicines. Nourse also mentions that Thomas Bowrey's English and Malayo dictionary published in 1701, translated dukun as 'physician, surgeon or apothecary' 
which has positive meanings (Nourse, 2013:414).

However, this view of the dukun changed and became negative and superior when the British administrator, Sir Thomas Stamford Raffles, ruled Dutch East Indies in 1811. Many British physicians, as well as British admiral and Orientalist William Marsden, said that the dukuns practised superstitious yet barbaric healing. (Nourse, 2013: 415-16).

The condescending view towards the dukun continued when the Dutch reoccupied Java in 1816. The strengthening of class segregation led to a lack of interaction between European physicians and the indigenous including dukuns. Moreover, after 1880, the development of medical knowledge, such as bacteriology, X-rays, and safer surgery methods made European physician more focused on bringing western medical knowledge to the colony rather than conducting research on local healing knowledge. All in all, they developed less respect for indigenous knowledge (Pols, 2009:175).

As a result of an expanding colonial healthcare system, the meaning of dukun took on a negative meaning. It became a term that defined 'bad' medicine within a dichotomy of traditional and modern medical practices.

Negativity towards dukun beranak became exacerbated when the Colonial Government planned to establish midwifery schools in the colony at the beginning of the $19^{\text {th }}$ century (Nourse, 2013: 415-16). By establishing midwifery schools, their ultimate intention was to replace the dukun beranak and provide western midwifery assistance for European and indigenous women (Hesselink, 2011:119). Europeans physicians' commentary on dukun as old, filthy, and superstitious placed them at anopposite pole towestern medical knowledge which was deemed more scientific, hygienic and modern.

Liesbeth Hesselink's in Healers on the Colonial Market describes the regulations of the Civil Medical Service of $1809^{1}$, and the assigning of municipal physicians in Batavia, Semarang, and Surabaya to train indigenous women as midwives. In 1817, European midwives were similarly obliged to train indigenous women as mid-wives however, the objectives were never fully realized.

In the same year, the Director of Agriculture, Arts and Sciences, C.G.C. Reinwardt was concerned about the dangers that resulted from the ignorance of dukun beranaks. He suggested appointing a municipal obstetrician to assist in cases of complicated deliveries, and also to teach midwifery to the dukun beranak. At the time, most physicians had an unsympathetic view of dukun beranak. They described them as illiterate, ignorant, and working on instinct; however, in the end, Reinwardt suggestions were never carried out (Hesselink, 2011:120).

1) The Civil Medical Service were still a subordinate to the Military Medical Service until the Reorganisation of the Civil Medical Services in 1906 to separate the military and the civil medical services (Hesselink, 2011:30). 
In December 1836, talks resumed on the creation of a training course for native midwives. The Head of the Medical Service, E.A. Fritze pointed out the importance of teaching midwifery to indigenous women to fulfil the midwifery needsin the Outer Islands so extending native midwives outside of Java. Fritze was succeeded by P.J. Godefroy, who agreed in principle to the continuation of the plan. However, when Godefroy proposed a plan to establish midwifery training to the Department of Finances in September 1839, it was rejected due the financial objections (Hesselink, 2011:120).

The attempt to establish this training was continued in October 1847, when the Head of the Medical Service, W. Bosch, suggested that the Dutch Indies government should improve midwifery assistance for the Javanese population. He proposed the establishment of a midwifery school for indigenous girls (Siandes et al., 1996:14). Bosch stressed that the ignorance and unhygienic treatment of the dukun could put women and babies at risk during labour. Furthermore, he considered it the government's duty to prevent child and maternal mortality by building better medical care facilities. Bosch's successor, G. Wassink had a similar view on the necessity of establishing a midwifery training program due to the inadequate modern medical knowledge of the indigenous midwives (Hesselink, 2011:121).

In 1851, a midwifery school was built between the military hospital and the student dormitories of the Dokter Djawa School in Welvtevreden, a suburb of Batavia. In 1875 the government sought to reorganize the school so they closed it temporarily. At the time, there were about 50 midwives in the colony, 41 of whom received a government stipend.

It took 16 years to finish the re-organisation of the school re-opening in 1891. Midwifery was taught based on a new method involving two or three years of on-site training program where the physicians acted as an instructor for a maximum of 18 native women. This scheme was quite different to the midwifery education delivered in 1850-1875 which wasin the form of a boarding school. In addition, instead of the student, it was the instructor who got the stipend and bonus if their student passed the final exam (Hesselink, 2011:231). The first student under this new system graduated in 1893. At the beginning of the $20^{\text {th }}$ century, twenty-nine women received their diplomas followed by another fourteen midwives..

When Jacques Hendrij Abendanon became the Director of Education, Religion, and Industry in 1900, he realised that to achieve the goal of replacing the dukun beranak and provide western midwifery assistance to indigenous people the number of native midwives needed to be increased. Afterwards, he submitted a proposal for an abridged six months midwives training program. This program would use similar material to the previous training course. Abendanon also proposed opening up the course to dukun beranak (Hesselink, 2011:247). A civil physician in Kediri, who taught midwifery 
to native girls, H.B. van Buuren found Abendanon's idea promising, but H. Bervoets, a missionary doctor who taught midwifery in Mojowarno, thought that is was notfeasible because six months was too short to complete the necessary training and the dukun beranak position was hard to replace. The commission and the government subsequently rejected Abendanon's proposal with midwifery training remain largely unchanged. ${ }^{2}$

Abendanon's concerns about midwifery led him to promote it on many occasions even though his short training proposal had been rejected. On his tour around Java, he met with the Regent of Jepara, whose daughter was Kartini (22 years old), and made an offer of a scholarship to the midwifery school in Batavia, which excited Kartini. ${ }^{3}$

In November 1902 Abendanon sent letters to the regional administrators to inform European physicians about the midwives training program. In August 1904, Abendanon sent another letter to the regional administrators with queries about getting support from physicians to become instructors and enrolling young girls to became midwifery students for the midwife training program. Abendanon did not send the letter to residents in Kediri, Manado, and Ternate since there were enough midwives in those regions (Hesselink, 2011:249).

However, it proved difficult to find young native women who could be enrolled since only a few of them had received primary education, a requirement to join the midwifery program. Midwives were also not widely used, since most Indonesians preferred to use the services of the dukun beranak. Thus, the training seemed to offer little prospect hence discouraging many from pursuing midwifery as a profession. Another reason may have been due to the fact that the training of native women was conducted in an apprenticeship relationship with older female practitioners. The delivery of the program by older male physicians teaching young native womenbroke traditional norms and gender relationships (Hesselink, 2011:250).

At the end of 1906 Governor-General J.B. van Heutsz appointed a Reorganising Commission to prepare for the separation of military and civil medical services. The chairman of the Reorganization Commission was Lieutenant Colonel J. Bijker. The members were the Inspector of the Civil Medical Sevice in Java G. Winkler, municipal doctor for Batavia L.J. Eilerts de Haan, Director Institute Pasteur and Landskoepokinrichting A.A. Nijland, Health Officer first-class D.L. Stibbe, and J. Schulein, a private doctor who worked in Soekaboemi. The secretary was the Department of Education, Worship and Industry officer H.G.C. Degent (Zondervan, 2016:116).

2) The commission was appointed in September 1902 and disbanded in 1903. The members were Civil Medical Service Inspector C. Winkler, Van Buuren, Bervoets, medical officer J.H.F. Kohlbrugge, Javenese doctors in Mojowarno, Ismael and six other members whose names are not listed. (Hesselink, 2011:248).

3) Kartini's letter to Estella Zeehandelaar, 11 October 1901. 
Willem Thomas de Vogel, a municipal physician in Semarang made a submission to the Reorganising Commission in 1906 on the midwifery school system. He was critical of the adequacy of native midwive's training based on his interactions with them. . He even considered them a greater danger than the dukun beranak. De Vogel found that a dukun did not perform any internal examination unlike a midwife. If the examination was performed unhygienically, it could lead to puerperal fever, a condition which had occurred in several deliveries assisted by native midwives (Hesselink, 2011:275). He suggested that ideally, dukun beranak should be trained as a nurse and the best nurses should be trained as midwives (Hesselink, 2011: 250).

In June 1908, the Reorganisation Commission published a report recognising the danger of dukun beranak, especially when assisting in difficult deliveries. However, they could not assess the number of native maternal and child mortality rates from either dukun beranak or midwives due to inadequate and unreliable statistical records. The commission assumed the unavailability of assistance during a difficult childbirth as the main cause of maternal and child mortality. Nevertheless, they did not think certified midwives would necessarily help the condition because native pregnant mothers preferred dukun assistance than western trained midwives. Thus, the commission regarded that the maternal birth service should still be largely done by dukun beranak as part of the traditional health care system.

Nevertheless, many people had a problem with continuing a modern native child health care system while still using mainly traditional practitioners. Van Buuren compiled a counter-proposal with detailed information about the dukun. He described dukun beranak as old, inadequate, and incapable. Van Buuren also distributed a questionnaire to the Nederlandsche Gynaecologische Vereeniging (Dutch Gynaecological Association) members who it turned out,agreed with him. Van Buuren agreed with the committee that a statistical collection of native health conditions remained a difficult task. Native officers from the villages in the regions were unable to provide adequate and robust statistics which is considered one of the most important components for the creation of an ideal health care system (Soerabaiasch Handelsblad, 11 Juni 1900:1).

After those discussions and debates, the reorganisation commission submitted their proposal to the Lower Chamber who agreed that the on-site midwifery training program in large clinics in the cities would be continued. The midwives would work in government clinics and be registered as nurses and paid a fixed salary. The old system of providing allowance midwives was withdrawn (Hesselink, 2011: 257).

In the 1920s the colonial government opened midwifery education with two schemes. Those who took three years of midwifery education after 
graduating from MULO were called Class 1 Midwives. While a nurse who took two years of midwifery education were called Class 2 midwives. The educational qualifications determined the allowances and salary received. Some hospitals in the cities also commenced delivering midwifery education, such as Budi Kemuliaan Hospital in Batavia, Palang Dua Maternity Hospital, and Mardi Waluyo Maternity Hospital in Semarang (Siandes et al., 1996:15).

Apart from the establishment of a Dutch Indies colonial midwifery school, there was another health project undertaken which wassponsored by the Rockefeller Foundation to improve health in Java. The Rockefeller Foundation is a philanthropic organisation based in America which had a mission to promote the well-being of humanity throughout the world, including the Dutch Indies. The Rockefeller Foundation was founded in 1913 by John Davidson Rockefeller, who also owned Standard Oil Company from 1870 (Baha'udin:3).

The foundation commenced a program to assist in hookworm control in the emerging nations of the world. Doctor Victor Heiser undertookthis philanthropic work from the Caribean to major port capitals in the tropical regions, such as the Dutch Indies. Heiser first arrived in Java in 1915. His work resulted in the successful intervention to control hookworms disease and led to a program of hygiene education which began in the 1920s (Hull, in Lewis \& Macpherson (eds.), 2008:140-141).

This project was conducted under the supervision of an American doctor, John Lee Hydrick along with his Dutch counterpart, Doctor Cornelis van Noort. Hydrick was a Rockefeller staff member from South Carolina who had worked in the Caribbean and the southern parts of the United States. Thus, he had experience of working with tropical disease and in tropical conditions. Rockefeller had recruited Van Noort to assist Hydrick and help him with the colonial administration. However, it transpired they could not get along, and Hydrick continued the project by himself (Hull, in Lewis \& Macpherson [ed.], 2008:142).

They started the hygiene project in 1924 and finished in 1939 and had conducted preliminary research on hookworm control. Hydrick used a similar method with his previous project in the Caribbean, which relied on persuasive acts and an educational approach. The first health campaign was held in Banten, a region known for its rebelliousness. After that, they continued to Kroya, Banyumas, and Central Java, where the people's character was more cooperative.

Importantly for this article, Hydrick also conducted basic hygiene training for dukun beranak so they could improve childbirth hygiene in the villages. He understood that most Javanese people preferred dukun beranak for handling childbirth. Through routine training, dukun beranak began to practice hygienic childbirth which enhanced safedelivery and prevented 
infectious disease in women and children (Baha'udin:19).

Baha'Udin shows that the Rockefeller approach was very different from the colonial government, who used an authoritarian approachsuch as prohibition (Baha'udin:14). For instance, the prohibition in relation to midwifery assistance in Kediri, May 1898. Wedono Kediri announced there would be two native midwives in the region, Djasminah and Tasminten who were Van Buuren student. The Wedono also registered dukuns and prohibited them from assisting a childbirth. Those who were either registered or yet to do so, and still provided assistance, would be punished for a period of two months. A dukun defied the ban by providing childbirth assistance. Hesselink noted that the native population could consider defying the ban as a victory over the coloniser (Hesselink, 2011:246-247).

European physicians also had a tendency to spread negative stories about dukun beranak. However, these stories mostly came from European doctors who were called after a dukun had failed to handle a complicated delivery. In other words, they had only seen the failures of dukuns. When a dukun had successfully handled a childbirth, the European medical officers had rarely been able to witness it (Hesselink, 2011:124).

The circulation of negative images of the dukun beranak by European doctors were, according to Nourse, a tactic by these doctors so that people would turn to midwives for assistance. Their juxtaposition of the old, traditional, brutal practices of the dukun with the young, scientific, Dutchtrained midwives supported a solution that excluded thedukun . The antidukun campaign continued throughout the colonial period. This was a very different approach to the more participatve one taken by the Rockefeller Foundation.

However, Hesselink noted that the opinions and horror stories of European medical personnel were not representative since most of the population felt satisfied with the services of the dukun. Nourse noted that the failure of the colonial government in changing people's preferrences in childbirth services was the result of their focus on spreading negative images of the dukun beranak (Nourse, 2013:417). The colonial government's use of an authoritarian approach rather than introducing midwifery gradually to the people without coercion, as those exerted in Kediri, also contributed to its failure (Hesselink, 2011:251).

European doctors condescending attitude toward indigenous knowledge was also a barrier. It made it difficult for them to realise the importance of the dukun, leading to a more limited spread of the practices of modern midwiferies. European medical officers not only underestimated dukun beranak, but certified native medical personnel as well. withseveral European doctors undervaluing the midwives' ability to assist women in labour.. For this reason, up to the end of the colonial period, this prejudicial 
barrier coming from the European doctors had resulted in a pitiful development and spread of midwifery techniques and also resulted in the low levels of midwifery development and service to the wider Indonesian population.

\section{Midwives after Independence}

There was an inadequate number of medical workers due to the Second World War and the Revolutionary War. Many medical personnel left their jobs since they were European and choose to be on the Dutch side and number of doctors in Jakarta decreased from 26 to 14 in the 1950's. Some hospitals and medical centres were inactive throughout the Second World War, although some hospitals were running normally. One of the medical centres which provided midwifery services was Budi Kemuliaan Hospital, which continued operation even during the Second World War.

Budi Kemuliaan Hospital was founded in 1917 by the Budi Kemuliaan Association, an organisation concerned with improving native healthcare. Since its establishment, this hospital had been a midwife training centre that accepted MULO graduates, with three years of education, and became a for prospective midwives. Initially, Budi Kemuliaan Hospital was located in Hospitalweg, Pejambon, Central Jakarta. In 1935 it was moved to Gang Scot, now known as Jalan Budi Kemuliaan. ${ }^{4}$

In 1945, Budi Kemuliaan Hospital had six consultation bureaus for pregnancy. However, because of the inadequate number of midwives, several bureaus were closed in mid-1946. During eight months from mid-1945 to mid-1946, the hospital had assisted some 1157 childbirths per month, with the lowest number being 451 in one month. Between 1945-1947, the hospital provided training for 163 prospective midwives (Kementerian Penerangan (Ministry of Information), 1950:403). Together with medical students from the Ika Daigaku medical school ${ }^{5}$, which was the former Stovia school in Batavia, these young women went to Surabaya under the auspices of the Indonesian Red Cross to support independence fighters. These included midwifery students Samiarti Martosewojo, Sulastri, Mardiana Firdaus, Rusdiati Koesmini, Supiah, Sufitah, Kus Adalina, Djoharnin, Maryati, Sumartinah, Clara Lantang, Corrie Probonegoro, Daatje Idris, Murni Kadarsih, and Soejati.

These women went to Surabaya under the supervision of Doctor Walter Tambunan and his medical student O.E. Engelen. They were instructed to stay behind the line of combat and provide medical help for the

4) https://rsbudikemuliaan.id/tentang-rs-budi-kemuliaan-jakarta/kartini-bagiansejarah-rumah-sakit-budi-kemuliaan/, (accessed 18 November 2020).

5) The name of the medical school in the Japanese colonial era. Formerly called Stovia, after independence it became Faculty of Medicine of the Indonesia University. 
freedom fighters. The work of these future midwives was important as there was an inadequate number of medical personnel during the war. When the war ended, only half of the young women continued working as midwives.

One year after the Netherlands recognised Indonesian sovereignty, the situation had improved. Some senior midwives arranged a conference in Budi Kemuliaan Hospital on 9 September 1950. At that meeting, they decided to establish an Indonesian Midwives Association (Ikatan Bidan Indonesia - IBI), which is based on Pancasila. IBI aimed to foster sisterhood and friendship between midwives and women in general. They implemented this by joining the women's federation, The Indonesian Women's Congress (Kowani) and the International Confederation of Midwives in 1956. They were trying to improve the welfare of mothers and children, provide guidance to dukun beranak in rural areas, and remove the tiers Class 1 Midwife and Class 2 (Mustika et al., 2001:35).

Their desire to provide guidance and training for dukun beranak can be interpreted as a decolonisation effort since they abandoned colonialeraauthoritarian practices of compulsion. . If in colonial times the medical elite maligned the dukun beranak, after independence, the midwives agreed to embrace them. They were not trying to replace or discriminate the dukun but to improve their understanding upon hygine and safety of childbirth service..

The association also desired to develop and disseminate the practice and science of midwifery. They decided to organise academic seminars, publish the association's magazine, build a library, and conduct radio broadcasts.

This spirit of solidarity continued during The National Conference of Midwives on 24 June 1951. Suleki (wife of the renowned sociologist Selo Soemardjan), Fatimah Muin, Sri Mulyani, Salikun, Sukaesih, and S. Marguna gathered to follow up on a decision they had made at their last discussion, eight months before the conference. Midwives from other regions, for instance, West Java, Yogyakarta, Central Java, Palembang, Bangka, and Banjarmasin also attended the conference. Midwives from Ambon, Medan, and Bukittinggi were unable to attend, but they sent a telegram stating their support and expressing their agreement with the conference results. The most resounding result of the conference was their statement fully supported the new nation's independence.

President Sukarno was impressed by the work of the midwives association and invited them to the Bogor Presidential Palace. Since they considered Sukarno's appreciation as a significant moment, they made that day the anniversary date of the association's founding.

In the same year, the Indonesian government initiated a program called Mother and Child Healthcare (Kesehatan Ibu dan Anak - KIA) in the city as well as rural areas. Another program was the Mother and Child Welfare Centre (Balai Kesejahteraan Ibu dan Anak - BKIA) which later became the 
training centre for dukun beranak. The midwives were also assigned to lead the medical centre as a substitute for doctors due to the absent or inadequate number of doctor in a rural area. They had to provide health services, such as prenatal and postnatal care, medical checkups for babies and infants, provide vaccinations, family planning, and related counselling for the villagers.

In Solo, Central Java in the 1950s, Dr Gunawan Nugroho witnessed that maternity clinics had been used as a base for providing health care activities for the surrounding areas. The Foundation of Christian Hospitals that owned this small clinic provided twenty beds. It was not a doctor who ran the daily management, but the midwives and auxiliary nurses. The doctor just came at certain times in order to supervise their work (Nugroho, in Newel [ed.], 1975:98).

At first, the midwives' duties were limited to monitoring pregnancies, handling childbirths, and postpartum treatments. However, in 1953, the Ministry of Health established another program called Additional Course for Midwives (Kursus Tambahan Bidan). With this additional training their duties could be extended to providing general public health services in rural areas (Siandes et al., 1996:12).

\section{The position of dukun beranak in independent Indonesia}

Several mothers and their babies had been waiting in front of Nek Ipat's house, a dukun beranak in Bekasi, West Java. They were sitting in a row on the terrace, patiently waited for the dukun bayi to massage their baby.

Unfortunately, the one whom they were waiting for was not at home. Nek Ipat, the dukun beranak was still massaging a baby (mijit bayi) in Tambun, Bekasi. When she arrived, she got herself some tea, and began to provide her service to the people in the queue, and massaged their babies.

Nek Ipat is still working as dukun beranak, an occupation which is quite rare to find nowadays. She admitted that over the last decade, people tend to go to midwives or obstetricians rather than dukun beranak to get assistance for childbirth. Furthermore, she said her daughter did not want to be dukun beranak and predicted that this traditional profession would no longer exist in the next decade. ${ }^{6}$

Most of the dukun beranak learn their skills from their elders, usually their mothers. Nek Ipat's mother and grandmother were also dukun beranak. She started learning about childbirth and post-labour treatment from her mother, who had been a dukun beranak for about 100 years. ${ }^{7}$ In the beginning, in the 1960s, Nek Ipat assisted her mother: helping to fetch clean water, preparing the traditional medicines, and bathing the baby. When finally her mother considered her ready to be her successor, Nek Ipat started doing

6) Personal interviewed, Bekasi, October 2017.

7) Nek Ipat's mother died at the age of 150. 
certain rituals which were prerequisites for the profession, including fasting for 120 days (topo pati geni). After undergoing all the stages, she was given the title of dukun beranak and started to help women deliver their babies in the 1970s.

Another dukun beranak is Imah, from Ngaglik, Yogyakarta. ${ }^{8}$ She had been assisting childbirths since 1948, following her mother's carier. Imah was the fifth generation dukun beranak in her family. Since she came from a low-income family, she never attended formal school and worked as a farmer and tobacco merchant when her services as a dukun beranak were no longer needed.

She believed that pregnant women should not drink cold water or consume ice because it could make the baby swell up and lead to a difficult delivery. Pregnant women are also forbidden to lift anything because it could induce heavy bleeding after labour (mayu getih). Moreover, if they craved certain foods, that craving must be satisfied. Otherwise, the baby would always be drooling after it was born.

Once, Imah helped a woman who had difficulty delivering her baby. She first tapped the mother's stomach several times while praying. She then used her thumb to hold on the woman hips and her big toe to push the woman's sacrum. If the newborn baby did not immediately cry, she applied pressure onto its chest. If there were still no response, she would hold the baby upside down until it cried.

After labour, most people asked the dukun to give them further treatment, such as a massage for both mother and baby, bathing the baby, and providing herbal medicine ( $j a m u$ ) for the mother. The home-based treatment and intensive care from the dukun somehow made people prefer to use the dukun beranak's service rather than doctors' or midwives' since they did not provide this kind of treatment. The lower cost was another consideration, as well as the familiarity of the dukun beranak's treatment and herbal medication, as it was the most common post-delivery treatment in the 1950s. Even the mother of B.J. Habibie, Indonesia's third president, used the assistance of dukun beranak to deliver one of her children (Habibie, 2001:10).

Another reason for using the services of dukun beranak was that it was hard to find a physician in the rural areas in the 1950s. Even in regencies near Jakarta, the number of available doctors and midwives were inadequate. The social gap between the patient and medical workers also made dukun beranak more accessible to the villagers.

For this reason, dukun beranak became the mainstay of the people since

8) Imah is not her real name. Her name is not mentioned in the document instead, it refers to her as dukun no. 9. She was 60 years of age when interviewed by Tri Handayani and Amin Yitno. Apa Kata Dukun Bayi, Rekaman Wawancara di Ngaglik, Yogyakarta. Pusat Penelitian dan Studi Kependudukan UGM. 1975. p. 62. 
both dukun and villagers came from a similar social class, which reduced the awkwardness in seeking assistance for a childbirth. People saw them as knowledgeable and respected their skills. Even in the 1970s, 80\% of Indonesians still used the services of dukun beranak to assist in childbirth and post-labour treatment (Tri Handayani and Amin Yitno:1975, 1).

\section{The Relationship between Midwives and Dukun}

Indonesian medical officers continued the attempts to provide healthier and safer delivery assistance in the postcolonial era. Nevertheless, the method used by Indonesian medical workers was very different from the colonial era.

In 1951, the Indonesian government initiated public health nursing programs, such as Mother and Child Healthcare (Kesehatan Ibu dan Anak - KIA) in the city and found Mother and Child Welfare Center (Balai Kesejahteraan Ibu dan Anak - BKIA) in rural areas. The programs were intended to be run in every sub-district, although this was difficult because of the lack of educated medical personnel.

Midwives and nurses stationed at a BKIA were tasked with providing health services for women and children. For women, the midwives at BKIA were tasked with conducting antenatal and postnatal checks, education on family planning, and general health care. BKIA also provides services for examining babies and children, vaccinations, immunisations, and educate people about nutrition (Siandes et al., 1996:12). They were also assigned to provide home-based childbirth assistance and gave hospital referrals for those experiencing labour difficulties. Besides their duty to assist childbirth, midwives at BKIA were also instructed to teach the villagers how to maintain environmental health, in their houses and schools.

One of the most interesting duties they had was to train dukun beranak on childbirth hygiene. However, many dukuns resisted the training, finding them uninspiring and stopped their training. Imah, one of the dukuns who had been trained in the 1950s in Ngaglik, only came twice because she was ordered to attend by her village head. After that, she never came to the course and continued to deliver babies traditionally. Indeed, even some of the dukun beranak who routinely came to the training had difficulty getting used to the medical kit.

The efforts to build community-based health care continued in the 1960s. The Public Health Nursing program was created as part of the implementation of the Health Law, which guaranteed every citizen the right to health services.

The Ministry of Health also stated that after independence, the outdated colonial mindset which benefited a select group people be abandoned. The new system must be compatible with Indonesian socialism. In the National Development Plan phase 1 (1961-1969), the development of polyclinics in the 
sub-districts was a priority in addition to building new hospitals (Departemen Kesehatan (Department of Health), 1966:59).

In this program, midwives were also assigned to train dukun beranak. They taught dukun beranak about hygiene practices when assisting childbirth, tools in assisting childbirth, and understanding a situation which needs a midwife. The dukun beranak learned about the danger of forced or accelerated childbirth, introduced abnormal pregnancy, puerperium, and postpartum.

Another thing taught was about superstitions or beliefs that could be detrimental to health. Midwives also told their dukun to encourage woman to take routine pregnancy checkups at the BKIA.

If the dukun beranak showed a sound understanding of this new knowledge and could carry out their duties following all health protocols, the training is continued with advanced materials, such as caring for pregnant women and babies and healthy food. The midwife was also in charge of supervising their dukun beranak.

In the New Order era, despite the general push for liberalisation, the idea of creating a democratic health service supported by many medical professionals and by the state. In 1975, Dr Firman Lubis, a medical lecturer at the University of Indonesia, conducted a medical project in Serpong,called Project Serpong. The project aimed to analyse the practices and treatments of dukun beranak and determine which parts should be kept and which should be discontinued. It was a project intended to modernise dukun beranak practices comprehensively and include them within the wider modern health care system.

He explained the approach towards dukun bayi in the sub-district of Serpong in Tangerang, West Java which was not to seek to exclude dukun beranak but rather to attempt to analyse dukun beranak's treatments and recommend those that should be kept and those that should be discontinued. He did not regard dukun beranak as a medical menace but as a practitioner of a traditional medical system that reflects the Indonesian social and cultural system (Lubis, 1975:59). The intention should not be to replace dukun beranak's role but to modify it through a partnership between dukun and midwives.

Serpong is located in Tangerang Regency, which has grown to become part of suburban Jakarta. In the 1950s, most of Tangerang were still composed of village with no electricity and with dirt roads and difficult to traffic for most cars. Although close to the capital city, it was very much part of rural Java. Up to the 1970s, the regency had only one doctor, Dr Kimar Wiramihardja, to handle the whole district. To run a local health centre in Serpong, Dr Firman Lubis needed to use non-electricity based energy devices, such as a kerosene powered refrigerator and oil lamp (Lubis, 2018:436). In more remote rural areas, health care facilities were more deficient, medical devices 
were inadequate, and other medical workers replaced doctors.

Since doctors were a rarity in the rural areas, in their absence midwives were often obliged to lead the medical centres. They had to provide health services, including pre and postnatal care, medical checkups for babies and infants, vaccinations, family planning, and counselling for the villagers. Similar to dukuns, midwives also provided home treatment for maternity and postnatal treatment. Generally, based on the Department's technical instructions book, every midwife was required to teach the residents about family health care, personal hygiene, and home-based post-labour care (Departemen Kesehatan, 1966:62). However, they did not routinely come to the patient's homes to provide prenatal and postnatal care.

The presence of midwives in the rural areas was essential to help the local populace to improve their health, to understand the importance of a clean environment, teaching them first aid, and improve the health of school children. Furthermore, midwives in the rural area used the BKIA as a training centre for dukun beranak.

Usually, in one village, there were no more than five dukun beranak. The dukun beranak were trained at the Mother and Child Welfare Centers with midwives as their mentors. They were taught everything about childbirth, postnatal, and medical devices. They learned to handle normal childbirth, understand unusual conditions, the need for healthy food for pregnant women and reducing superstitions about pregnancy, and mother and child health. If they came across difficult cases of child delivery, they were required to report it to the midwife (Lubis, 2018:65).

Nunik Endang Sunarsih was a midwife in Yogyakarta in the 1980s who trained as a dukun beranak. She provided the dukun withmedical kits containing a clamp, scissors, alcohol, and bandages to replace unhygienic traditional kit. Before training, the dukun beranak often used a sharp piece of bamboo (welad) to cut the umbilical cord, and cinders to close the wound. ${ }^{9}$

The midwives taught the dukun beranak to replace welad with a clamp and scissors. After use, the dukuns were taught to sterilise the tools by boiling them in water for about 30 minutes. The dukun was also forbidden to use turmeric or cinders to cover the baby's navel but instead, use alcohol and bandages. Nunik recounted that some dukun beranak even told mothers not to bath before the wound healed when in fact this could lead to infection due to lack of hygiene.

Firman Lubis stated that the unsterile practices of dukun beranak could cause tetanus infections for mothers and even possible death for the child. ${ }^{10}$

9) Interview with of Nunik Endang Sunarsih, a midwife who trained as a dukun beranak in the 1980 s.

10) Firman Lubis tried to improve the mother's and child's health while not disrupting the local beliefs which could lead to conflict between the dukun, medical workers, and the local populace. 
Therefore, training the dukuns to be more hygienic was of paramount importance and the midwives' primary mission.

Nunik and Sri Suharyati ${ }^{11}$ share a similar story when they were supervising dukun beranak. In Yogyakarta, Nunik held the training once every five weeks and also checked whether the medical kit needed to be restocked. When Suharyati found the medical kit looking unused, it made her suspicious that the dukun did was still using their traditional methods of handling childbirth.

Nek Ipat, who attended the training in the 1990s in Bekasi, said that her midwife would check the medical kit and questioned her about the assistance she provided over the last month. She admitted that she would often feel concerned that the midwives would get angry at her if the medical kit was broken or lost. Nevertheless, she tried to obey all of the midwives' suggestions on the importance of hygiene and regularly sterilised her kit.

In Serpong, Firman Lubis taught midwifery to two mak paraji. Their names were Mak Kancas and Mak Icot. Even though they were old and illiterate, Firman taught them patiently and tried to make the courses fun. The midwives, doctor, and mak paraji even had an arisan (rotating savings and credit group) at every meeting to strengthen their bond.

With his medical anthropology approach, Firman Lubis was deeply aware that using force, coercion, or power would only createconflict between the midwife, dukun beranak, and the people. Firman Lubis did not try to eliminate dukun beranak. He tried to describe and categorize dukun beranak methods, and determine those which can be maintained and those which should be replaced with more suitable methods to a medical standard.

\section{Conclusions}

Since the beginning of the $19^{\text {th }}$ European physicians aimed to replace $d u k u n$ beranak. They were trying to provide western midwifery assistance for European and indigenous women by establishing midwifery schools in 1851 .

This development then shifted the meaning of dukun to take on a negative connotation because of this competition with midwives andnegative commentary from European physicians' who described dukun as old, filthy, and superstitious. In so doing created a barrier between traditional and modern medical practices.

Besides the colonial attempt to replace dukun beranak with native midwives, there was work done from the Rockefeller Foundation to improve hygiene. This American philanthropic organisation held training for dukun beranak to apply hygiene practices which could improve childbirth safety in the villages.

11) Sri Suharyati was a midwife who trained dukun beranak in Makasar, East Jakarta in the 1980s. 
The Rockefeller approach was very different from the colonial government who banned dukun beranak to assist in childbirth after they sent two recently graduated midwives to Kediri. The colonial government failed to understand the indigenous perspective and preferred to use prohibition and condescending acts. This contributed to the failure to establish midwifery assistance in the colony.

The midwives association, established after the Dutch recognised Indonesian Independence brought some change to the colonial system of midwifery. For instance, the association agreed to erase first and second class midwives and create sisterhood among women. The associations also agreed to train dukun beranak about medical standards instead of trying to replace or discriminate against the dukun.

Firman Lubis also used a similar approach on his project in Serpong in the 1970s. Lubis did not regard dukun beranak as a medical menace but as a traditional medical system that reflects the Indonesian social and cultural system. In his research, Lubis attempted to analyse the treatments used by dukun beranak so he could determine which should be kept or discontinued. Lubis believe, banning dukun beranak to provide assistance could only lead to resistance from the people.

These contrasting approaches andmethods marked the differences in the relations between medical staff and dukun and different physicians' perspectives towards dukun beranak in the colonial era and the postindependence era.

\section{References}

\section{Books}

Departemen Kesehatan (1966). "Pedoman dan Berita”. Jakarta: Departemen Kesehatan.

Departemen Kesehatan (1970). "Pedoman dan Berita”. Jakarta: Departemen Kesehatan.

Hesselink, Liesbeth (2011). Healers on the Colonial Market. Leiden: KITLV Press. Kementerian Penerangan (1950). Republik Indonesia: Kotapradja Djakarta Raja. Jakarta: Kementerian Penerangan.

Koentjaraningrat (1964). Masyarakat Desa di Indonesia Masa Ini. Depok: UI Press. Lubis, Firman (2018). Jakarta 1950-1970. Depok: Masup Jakarta.

Lubis, Firman (1975). Proyek Serpong. "Cara Pendekatan Antropologi Medis dalam Masalah Dukun Bayi di Kecamatan Serpong”. [unpublished?]

Mustika, et al. (2001). Bidan Menyongsong Masa Depan.Jakarta: Pengurus Pusat Ikatan Bidan Indonesia.

Muzakir (2018). Dukun dan Bidan dalam Perspektif Sosiologi. Makassar: Sah Media. Newell, Kenneth W. (1975). Health by The People. Geneva: World Health Organization.

Siandes, Sudar et al. (1996). Profesi Bidan Sebuah Perjalanan Karier.Jakarta: Pengurus Pusat Ikatan Bidan Indonesia. 
Tanjung, Thamrin (1993). Soal-Soal Ilmu Kebidanan Fisiologi.Jakarta: Penerbit Buku Kedokteran EGC.

Handayani, Tri and Amin Yitno (1975). Apa Kata Dukun Bayi, Rekaman Wawancara di Ngaglik, Yogyakarta. Yogyakarta: Pusat Penelitian dan Studi Kependudukan UGM.

Yayasan untuk Indonesia (2005). Ensiklopedi Jakarta: Culture and Heritage. Jakarta: Dinas Kebudayaan dan Permuseuman.

\section{Journal Articles}

Baha'Udin (date). "Propaganda Kesehatan Rockefeller Foundation di Jawa pada Akhir Masa Kolonial” (journal?)

Boomgaard, Peter (1993). "The Development of Colonial Health Care in Java”. Journal of the Humanities and Social Sciences of Southeast Asia and Oceania. p.77-93.

Hull, Terrance (2008) "Conflict and Collaboration in Public Health: The Rockefeller Foundation and the Dutch Colonial Government in Indonesia", in Milton J Lewis and Kerrie L Macpherson, Public Health in Asia and Pacific, Abingdon: Routledge, p. 140-152.

Nourse, Jennifer (2013). "The Meaning of Dukun and Allure of Sufi Healers". Journal of Southeast Asian Studies, Vol. 44/03:400-422.

Pols, Hans (2009). "European Physicians and Botanists, Indigenous Herbal Medicine in the Dutch East Indies, and Colonial Networks of Mediation”, East Asia Science, Technology and Society: an International Journal, vol. 3:173-207.

\section{Dissertation}

Zondervan, Sjoerd (2016). "Patients of The Colonial State", doctorate dissertation, Maastricht University.

\section{Interviews}

Nek Ipat, October 2017.

Sri Suharyati, October 2017.

Nunik Endang Sunarsih, January 2020.

\section{Manuscript and articles}

Kartini, Letter to Estella Zeehandelaar, 11 October 1901.

Nur Janti, “Dukun beranak Ditelan Zaman”, Historia.id, 20 October 2017, accessed 24 January 2020.

Rsbudikemuliaan.id, “Sejarah Rumah Sakit Budi Kemuliaan”, accessed 18 November 2020.

Van Buuren, Soerabaiasch Handelsblad, 11 Juni 1900.

Naskah Lengkap Kongres Obstetri Ginekologi Indonesia Ketiga. Medan 1976. 